\title{
Building Institutional Capacity to Plan for Climate Neutrality: The Role of Local Co-Operation and Inter-Municipal Networks at the Regional Level
}

\author{
Vincent Wretling * (i) and Berit Balfors
}

check for

updates

Citation: Wretling, V.; Balfors, B. Building Institutional Capacity to Plan for Climate Neutrality: The Role of Local Co-Operation and Inter-Municipal Networks at the Regional Level. Sustainability 2021, 13, 2173. https://doi.org/10.3390/ su13042173

Academic Editor: Eduardo José Rocha Medeiros

Received: 22 December 2020

Accepted: 13 February 2021

Published: 18 February 2021

Publisher's Note: MDPI stays neutral with regard to jurisdictional claims in published maps and institutional affiliations.

Copyright: (c) 2021 by the authors. Licensee MDPI, Basel, Switzerland. This article is an open access article distributed under the terms and conditions of the Creative Commons Attribution (CC BY) license (https:// creativecommons.org/licenses/by/ $4.0 /)$.
Department of Sustainable Development, Environmental Science and Engineering, KTH Royal Institute of Technology, S100 44 Stockholm, Sweden; balfors@kth.se

* Correspondence: vincentw@kth.se

\begin{abstract}
The institutional capacity of local authorities to integrate climate change mitigation aspects into spatial planning is of vital importance. This paper sets out to investigate this capacity in the county of Stockholm, Sweden, by surveying 26 municipalities and analysing two case study municipalities through participation in workshops and interviews. The study shows the need both for a local energy and climate policy domain that can be integrated into spatial planning as well as dedicated personnel to maintain this policy, thereby securing knowledge resources within the organisation. Additionally, the importance of relations to and repertoires for interacting with politicians is highlighted. Lastly, the study demonstrates the complementary added value of a regional-local network administered by the County Administrative Board, spreading learning examples and diffusing theoretical knowledge, as well as sub-regional, inter-municipal networks that enable the transfer of more practical knowledge and provide a platform for concrete action.
\end{abstract}

Keywords: spatial planning; comprehensive planning; institutional capacity building; governance networks; climate change

\section{Introduction}

The escalating climate change has been referred to as a wicked problem, as it comprises four key features: "time is running out; those who cause the problem also seek to provide a solution; the central authority needed to address them is weak or non-existent; and irrational discounting occurs that pushes responses into the future" [1] (p. 124). These circumstances call for governmental actions at a variety of levels (including local, regional, national and supra-national) by a plethora of stakeholders and in multiple sectors $[2,3]$.

Local governments have been identified as central players in efforts to bend the curve of anthropogenic greenhouse gases emissions [4,5]. Prevailing arguments for this central role are that they are unhampered by the complex negotiations transpiring at the international level [6], that they are the governmental level closest to the citizens [7], and that they principally have wide-ranging responsibilities in planning and providing services to citizens [8]. Given that local communities play an important role in land-use planning, there is a need to integrate aspects of climate change mitigation into land-use planning in order to spatially plan for carbon-neutral societies [9]. Climate change mitigation aspects encompass measures and strategies related to energy efficiency, for example, to promote densification, to prioritise transit-oriented development, and to plan for mixed land use in order to reduce energy demand and transport needs [10,11]. Other climate change mitigation aspects that can be considered in spatial planning include planning for largeand small-scale renewable energy production, such as wind power and solar power [12].

The ability of local governments to provide such responses to mitigate climate change is highly dependent on their institutional capacity [13-15]. This concept captures "the ability of administrative and government organizations and agencies to respond to and manage 
current social and environmental challenges through decision-making, planning and implementation processes" [14] (p. 187). Institutional capacity was defined by Healey et al. [16] as consisting of three dimensions: (i) knowledge resources, (ii) relational resources, and (iii) mobilisation capacity. This conceptualisation has its roots in the collaborative planning paradigm, which emphasises collaboration with a wide range of stakeholders and consensus-seeking [14,17]. This applies both to the involvement of internal stakeholders, for example, having cross-sectoral planning processes to include more perspectives and competences, and to the involvement of external stakeholders that may have a stake in the process [18].

A central component for building institutional capacity is the function of governance networks for interacting with different stakeholders. This is also reflected in the literature of climate planning and governance, as there has been a rise both in the number of authorities participating in municipal networks for local climate governance-chiefly transnational networks such as Covenant of Mayors and Cities for Climate Protection-and the research interest of such networks [4,19]. According to Gustavsson et al. [20] (p. 71), municipal networks "have the potential to function as vital channels for the dissemination of information, best practice, and knowledge, and thereby speed up the process of capacity building, not least at the local level". Despite the focus on transnational municipal networks, Kern and Alber [21] argue that horizontal and vertical collaboration are especially important within metropolitan regions, as mitigative efforts need to transgress municipal borders, not least with regard to urban form and urban planning. This accentuates the potentially vital role of municipal networks also at a regional and sub-regional scale.

In Sweden, the Swedish Energy Agency has provided funding to the County Administrative Boards (CABs) to initiate capacity building projects in order to integrate aspects of climate change mitigation into spatial planning, targeting relevant local and regional actors. This support is specifically aimed at municipalities, as they are recognised as essential actors for Sweden's sustainability efforts due to their broad responsibilities with regard to providing services and local planning [22]. Despite the recognised centrality of the Swedish municipalities for integrating climate change mitigation aspects into spatial planning and the importance of networks for building their institutional capacity, the intersection of these two topics has not been fully explored in the Swedish context. One of the initiated projects, EKLIPS (Energy and climate in spatial planning through local and regional co-operation), in which the research presented here was conducted, provided a timely opportunity to explore this topic.

Through the lens of institutional capacity building, this paper sets out to analyse the process for integrating climate change mitigation aspects into municipal spatial planning in Stockholm County. More specifically, it aims to:

(i) investigate the current capacities, challenges and opportunities for integration of climate change mitigation aspects into spatial planning,

(ii) explore forms and needs for local co-operation in the comprehensive planning process as well as inter-municipal collaboration through governance networks.

\section{Institutional Capacity Building}

The following paragraphs, which expand upon what the three different dimensions of institutional capacity entail, are based on the work of Healey [23], Healey et al. [16] and Healey et al. [13]. The dimension of knowledge resources intends to capture the range of accessible knowledge in different forms (explicit and tacit, systematised and experiential). Furthermore, it encompasses the frames of reference or discourses through which this knowledge is interpreted and given meaning, as well as the extent to which the range of knowledge and frames of reference are commonly shared among different stakeholders and integrated into different policy development spheres. Additionally, it encompasses openness to and learning from new ideas.

Relational resources are conceptualised as the range of stakeholders involved, with an emphasis on the different webs or networks of relations into which actors are woven. 
The different forms and structures of these webs (i.e., their morphology) can affect who gains access to these forums, and the network integration, meaning how well interconnected different webs are, will impact how information and ideas can flow between these webs. Lastly, the notion of power relations refers both to how relations are managed and can be accessed (open and building on mutual trust versus closed and discouraging), as well as where resource and allocating power is positioned, both in the network and in broader governance structures.

The aspect of mobilisation capacity includes a political opportunity structure, i.e., the perceptions by different stakeholders with respect to the desirability, opportunities and constraints for institutional change. It also entails the institutional arenas used and created by stakeholders, different mobilisation forms for collective action (the repertoires) and the presence or absence of change agents in key stages.

The institutional capacity of a local authority is under constant change, and these dimensions should thus be seen as dynamic, as they are both drawn upon in planning and governance initiatives and simultaneously generated and moulded through these practices, constantly influenced by both external forces and internal evolutions [24]. Principally, the institutional capacity of a local authority to respond to an environmental or societal challenge would be expected to be built up over time, as knowledge is accumulated in the organisation and common frames are established among a broad range of actors who co-operate to respond to this challenge. This also highlights the interdependency of the dimensions of institutional capacity, for example, as being embedded in multiple, large relational webs can bring access to larger knowledge resources and having access to both of these types of resources can allow a common frame to be established around which to mobilise while having the inherent interconnectedness needed for mobilisation. The three components of institutional capacity, their interdependence, and its development over time are visualised in Figure 1.

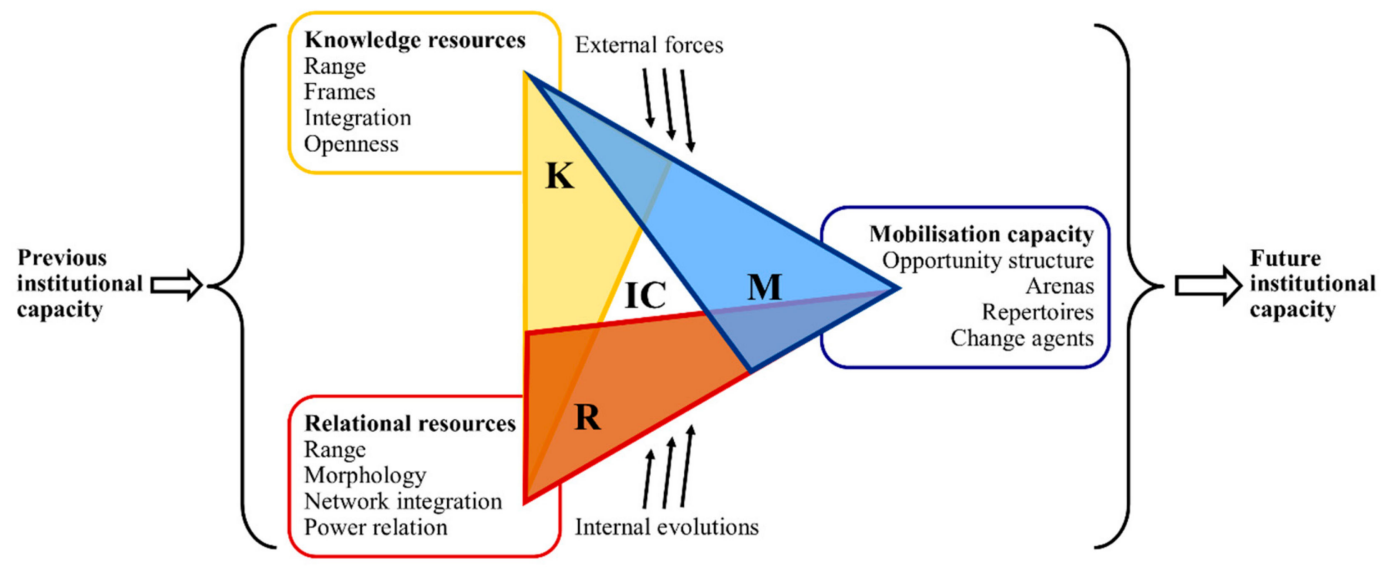

Figure 1. Conceptualisation of the development of institutional capacity. Based on Healey et al. [16], Healey et al. [13] and Healey [23]. Abbreviations: IC (Institutional Capacity), K (knowledge resources), R (Relational resources), M (Mobilisation capacity).

\section{Spatial Planning and Climate Governance in Sweden}

The Swedish planning system is characterised by a high level of decentralisation. This is manifested in what is referred to as the planning monopoly, meaning that the 290 Swedish municipalities possess sovereignty with regard to planning for the use of land and water [25]. This planning monopoly encompasses the two statutory planning tools of comprehensive planning and detailed development planning [26]. All Swedish municipalities are obligated to have an updated comprehensive plan, which is a strategic plan that addresses the long-term spatial and overall development of the whole municipality [27], making it a key forum for territorial governance in Sweden. Although the comprehensive 
plan is not legally binding itself, it should be indicative of the planned land and water use and should steer the legally binding detailed development plans [28].

In addition, the Swedish municipalities ought to have a municipal energy plan that is up-to-date concerning the supply and distribution of energy [29]. However, due to the deregulation of the energy system and the growing recognition of the escalating climate change crisis since the turn of the millennium, many municipalities develop municipal energy and climate strategies on a voluntary basis [30,31]. In practice, municipal energy plans in recent years have adopted a broader scope that includes a focus on climate change mitigation [32].

The municipalities are politically controlled authorities, as a publicly elected municipal council decides upon a municipal executive committee that determines which standing committees the municipality should have and chooses committee members [33]. Each standing committee is given a certain field to be responsible for (for example environment, infrastructure, social care), and often there is a corresponding administration for each committee, where officials carry out day-to-day activities (Ibid.). As the Swedish municipalities have been given broad responsibilities not delimited to spatial planning and energy planning, but also, for example, building permitting, environmental protection, and waste management, many different administrations are of relevance in a comprehensive planning process. This puts a demand on working intersectorally and involving officials from many different administrations to gain their perspectives and achieve an integrated planning process. In this way, access is gained to a wide range of knowledge that simultaneously can be spread to participating actors as a part of the process to build institutional capacity. Evidently, the municipal politicians and administration executives are also vital actors for the institutional capacity building, for example by contributing to shaping the possibilities for mobilisation.

As mentioned above, the County Administrative Board is an important actor at the regional level in Sweden. They represent the central state in each of the 21 counties, and in relation to spatial planning, they have both an advisory and a supervisory role. They work to provide municipalities with advice and support in how to plan according to the Planning and Building Act, but also to ensure that national interests are taken into account in local planning $[34,35]$. A part of the CABs' responsibilities is to review both municipal comprehensive plans and detailed development plans. However, it has been reported that tensions can arise when the $\mathrm{CAB}$ tries to steer local spatial planning towards the integration of climate change responses, as the municipalities want to ensure their autonomy [34]. Furthermore, as a part of their advisory role, the CABs are, since 2008, instructed to develop Regional Climate and Energy Strategies aiming to reduce climate change, increase energy efficiency, increase renewable energy production and contribute to a more efficient transport system [36]. This should be done in co-operation with relevant stakeholders, such as municipalities, and the CABs have thereby been given a meta-governor role, i.e., undertaking responsibility as well as aiming to coordinate and steer the activities of other autonomous actors (Ibid.).

\section{Materials and Methods}

The research design consists of a dual approach to investigate the stated aims of the paper. A survey was used to provide an overview of the current conditions within the municipalities of Stockholm County. Additionally, two case study municipalities were selected for interviews and participation in comprehensive planning workshops in order to gain a deeper insight into the factors that affect their institutional capacity. As the survey enables quantitative investigation, this mixed methods research approach, i.e., combining both quantitative and qualitative methods, intends to strengthen the validity of the study through triangulation [37]. 


\subsection{Presentation of Stockholm County and the Case Study Municipalities}

Two case study municipalities were selected, Danderyd and Nykvarn, which were both in the beginning stages of their respective comprehensive planning processes. Apart from the appropriate timing, these municipalities were selected because they differ from each other in several factors, as underlined below, after a brief introduction of the county in which they are located.

Stockholm County, situated by the Baltic Sea in the east-southeast of Sweden, is one of 21 counties in Sweden. Stockholm County is a metropolitan region that includes Sweden's capital, the city of Stockholm. It has over 2 million inhabitants, which is more than one-fifth of Sweden's total population. There are 26 municipalities in Stockholm County, two of them being our case study municipalities.

As underlined by the key statistics presented in Table A1 in Appendix A, the case study municipalities Danderyd and Nykvarn differ in many ways. Danderyd is located just north of the municipality of Stockholm, with approximately 33,000 inhabitants, and can be considered an urban municipality. Nykvarn, on the other hand, is located about $50 \mathrm{~km}$ from the city centre of Stockholm, furthest to the west in Stockholm County, with approximately a third of the population of Danderyd. This gives Nykvarn more of a peri-urban character. Figure 2 shows the case study municipalities' geographical location in relation to each other and the municipality of Stockholm. This means that the possibilities and challenges concerning the integration of aspects of climate change mitigation into spatial planning are likely to differ, thus providing insights that can be generalised to and applied to a broader range of municipalities.

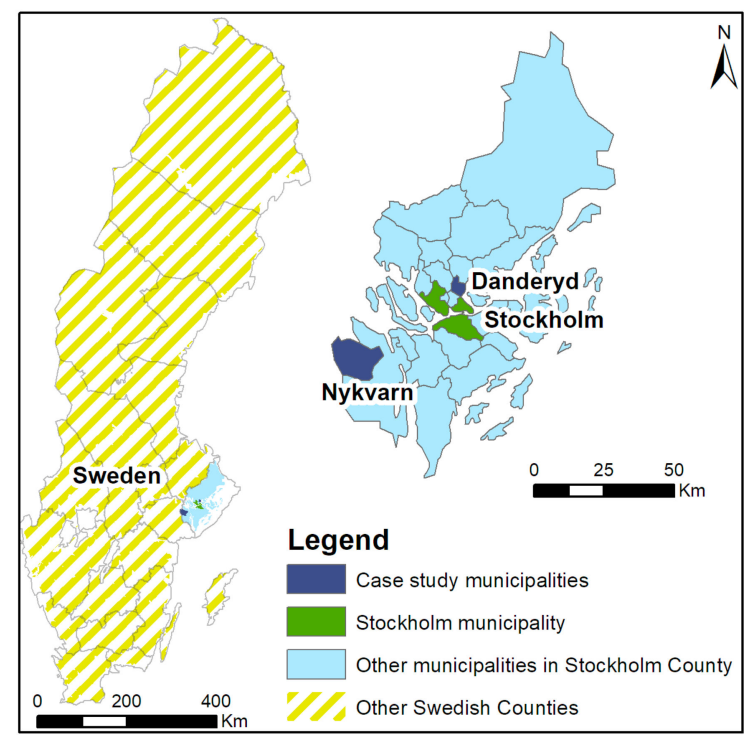

Figure 2. Visualisation of the geographical position of the case study municipalities in relation to Stockholm municipality.

\subsection{Interviews and Workshops in Case Study Municipalities}

Interviews were held with key officials working with strategic planning and strategic energy and climate change mitigation efforts in each case study municipality. These officials were selected because their responsibilities were recognised as relevant for the integration of climate change mitigation aspects into spatial planning in the case study municipalities, and they were thus expected to be able to provide insights and perspective on this topic. The selected interviewees included a comprehensive planner and an environmental strategist in Nykvarn, as well as a comprehensive planner, an energy and climate strategist and an environmental coordinator in Danderyd. The interviews were semi-structured [38], using an interview guide (enclosed in Table A2 in Appendix B) with open-ended questions and some prepared follow-up questions while leaving room for 
some flexibility depending on the answers of the interviewee. The interviews, which lasted approximately one hour each, were conducted and recorded through an online video meeting platform and subsequently transcribed.

Additionally, three workshops focusing on the integration of climate change mitigation aspects were held for each case study municipality as a part of their comprehensive planning processes. The comprehensive planner of each municipality and an external process facilitator agreed whom they wanted to invite for these workshops. Participants varied between the two municipalities and between each workshop, but in principle, the municipal officials belonging to the working group, representatives from the County Administrative Board of Stockholm and the research group, and the external process facilitator were present. A detailed list of participants in each workshop can be found in Table A3 in Appendix C. The role of the researcher during the workshops was to be an observer, and notes were taken during these workshops with a focus on the involvement of relevant internal and external stakeholders as well as how this affected the planning processes.

\subsection{Survey}

A survey was sent out to all comprehensive planners and to all municipal officials tasked with addressing strategic energy and climate matters (in this paper referred to as energy and climate strategists) in the 26 municipalities within Stockholm County. The survey addressed the municipalities' current capacities for integrating aspects of climate change mitigation into spatial planning, potential challenges and opportunities for enhanced integration, and different forms of horizontal and vertical co-operation in relation to this. In essence, the same survey was sent to the comprehensive planners and the energy and climate strategists, although questions relating to stakeholder involvement in planning processes were tailored to each target group. The survey for comprehensive planners had 19 respondents, and the survey sent to energy and climate strategists had 17 respondents, giving the surveys a response rate of $73 \%$ and $65 \%$, respectively. The surveys contained both open and closed questions in order to facilitate comparison and the extraction of descriptive statistics while still allowing the respondents to elaborate and nuance their standpoints.

\subsection{Analysis of Results}

An analytical framework was developed prior to the data collection and formulation of research aims. This analytical framework consisted of the theoretical framework and key issues emerging from the literature review of the fields of spatial planning and climate governance. Three themes were identified in this analytical framework, which guided the formulation of survey and interview questions, and the gained results were subsequently clustered into the same themes, as presented in Section 5. The findings were interpreted through the theoretical lens of institutional capacity building in order to gain an understanding of how the three dimensions of institutional capacity, i.e., knowledge resources, relational resources and mobilisation capacity, are constituted and how they interact concerning the integration of climate change mitigation aspects into spatial planning. For each theme, the empirical findings are presented, followed by a theoretical analysis concerning their implications from the perspective of institutional capacity building.

\section{Results and Analysis}

\subsection{Current Capacities, Challenges and Opportunities}

\subsubsection{Survey}

The survey shows that, to some extent, many municipalities are already addressing the question of integrating climate change mitigation aspects into spatial planning (Figure 3). Simultaneously, it highlights the fact that there is room for improvements in their institutional capacity in this regard. 


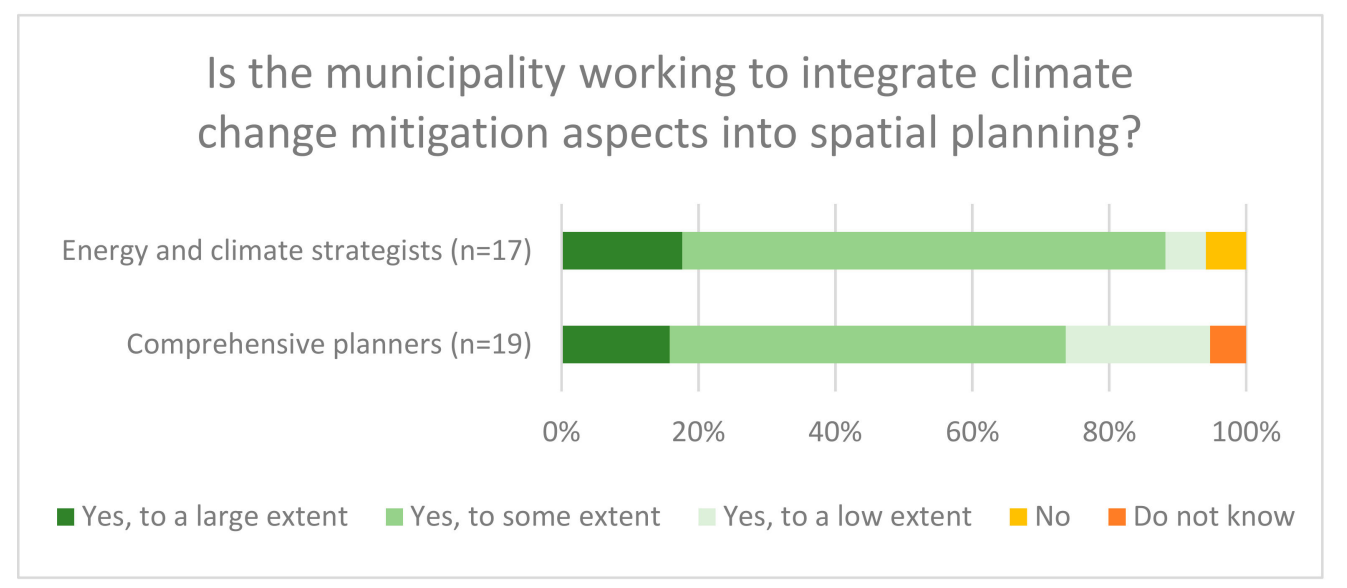

Figure 3. The extent of integration of climate change mitigation aspects into spatial planning.

Objectives, plans and strategies at the municipal level are considered to be the most important factors for providing guidance in the municipalities' efforts on this theme, closely followed by corresponding entities at the regional level (Figure A1 in Appendix D). The policy documents that are considered most important in guiding the municipalities' energy and climate strategic efforts are the Comprehensive Plan, the Energy Plan and/or environmental programme. Furthermore, the regional development plan produced by Region Stockholm and the Regional Climate and Energy Strategy produced by the CAB are considered aids to municipal planning, though the latter is only mentioned by energy and climate strategists.

The biggest challenges for the increased integration of climate change mitigation aspects into spatial planning identified by the respondents were: (i) lack of knowledge, both internally among municipal officials and politicians as well as externally among stakeholders such as real estate companies; (ii) that it is a complex problem for which technology and knowledge are being developed at a quick pace; (iii) economic barriers, as dedicating personnel to work with the issue and implementing measures can be perceived as costly; and (iv) lack of municipal mandate regarding certain issues, for example, if the municipality does not own the local energy company, they cannot control the use of energy sources. When asked if they need knowledge-enhancing measures, and if so, what type of measures are needed, the respondents called for learning examples with regard to methods, working procedures and concrete measures, as well as the continuous building of knowledge through seminars for the dissemination of novel findings and exchange of knowledge and experiences among practitioners.

\subsubsection{Case Study Municipalities}

There are both similarities and differences concerning current procedures and capacities in the case study municipalities. Among the interviewees from Nykvarn, there is consensus that no structured work is currently being done concerning the integration of aspects of climate change mitigation into spatial planning in Nykvarn. The main reason given for this is a lack of human resources. The environmental strategist interviewed in Nykvarn only works strategically with the municipality's long-term sustainability and development less than half-time, and energy and climate strategic concerns are just a part of the wide palette of matters this official is asked to address. According to the interviewees, this is related to a lack of interest and ambition among politicians and municipal administration executives to fund both the person-hours needed for the relevant processes and concrete measures.

The situation in Nykvarn stands in contrast to the municipality of Danderyd, where, in practice, the interviewed energy and climate strategist and the environmental coordinator share the responsibilities of the equivalent half-time position in Nykvarn. The officials in Danderyd also feel that their ongoing efforts on the topic are well-coordinated, especially 
in their current processes with the comprehensive plan and the environmental and climate programme under development. The Danderyd officials share the perception that funding is a barrier, but still think that their politicians show an interest in and willingness to interact. Political will can nevertheless interfere, as is demonstrated by the unwillingness to impede the possibility to own and use private cars. In Danderyd, this led to a situation where neither drafts of a traffic strategy nor a parking policy produced by Danderyd officials some years ago got adopted by the politicians. This political reluctance to regulate the use of private vehicles is also recognised by the Nykvarn interviewees.

Neither of the case study municipalities had addressed climate change mitigation to any great extent in their previously adopted comprehensive plans. In Nykvarn, politicians had decided to keep a high ratio of single-family detached housing in the recent housing development, which was proposed as corridors stretching from the urban areas of Nykvarn towards Lake Mälaren, where preconditions for public transport, district heating and water and sewage infrastructure were poor. Danderyd, on the other hand, has not revised their comprehensive plan since 2006, as the municipality has been politically divided regarding whether to re-route a highway through a tunnel, resulting in the failure to adopt a draft comprehensive plan in 2013. Their current comprehensive plan is considered out-of-date and does not address climate change mitigation to any great extent, which makes it more difficult to, for example, inhibit small-scale housing in more secluded locations with limited access to public transport.

As exemplified by the quote below, all the interviewed officials think that the Comprehensive Plan is the most important forum for integrating climate change mitigation aspects into spatial planning, as the Comprehensive Plan should show the political will for the long-term spatial development of the municipality. Thus, they have high expectations for their coming Comprehensive Plans.

To integrate [aspects of climate change mitigation] into the Comprehensive plan is the most important. The topic may well be expanded on in a strategy of its own, but for it to really have a link to land use, this is where the topic should be addressed.

(Comprehensive planner in Nykvarn. Authors' translation.)

Furthermore, both municipalities seek more coherence between the comprehensive plan and their respective policy document with a focus on environmental sustainability (the Environmental and Climate Programme in Danderyd being under development and the Environmental Programme in Nykvarn). As expressed in the quote below, this is then intended to steer detailed development planning and the building permit process.

We want to sync the [comprehensive plan and the environmental and climate programme], we want to have a common thread ... In particular, this common thread should come from [the strategic policy documents], for example, from comprehensive plan to detailed development plan to building permits.

(Comprehensive planner in Danderyd. Authors' translation.)

The interviewees report that the most important positions for these efforts are the comprehensive planner and the official(s) addressing long-term sustainability issues, such as the energy and climate strategist/environmental strategist, as they have competences for working strategically with the long-term development of the municipality.

The current work of both municipalities revolves around aiming to make new housing development slightly denser and more large-scale, localised near public transport and with good preconditions for district heating as well as walking and cycling opportunities. Danderyd is also promoting the deployment of EV charging stations and enhancing proximity and accessibility to recycling stations.

\subsubsection{Analysis: Institutional Capacity Building}

The survey results indicate that many municipalities are in the transformational phase of building institutional capacity for the integration of climate change mitigation aspects 
into spatial planning, a notion that is supported by the case study municipalities, where the officials actively work to enhance their efforts and routines. The number of personnel and the portion of their workload dedicated to strategic sustainability efforts are likely to affect the institutional capacity building in multiple ways. In this sense, Nykvarn might be said to have weaker knowledge resources (Healey 1998), and may not be able to dedicate as much time and effort to the acquisition and application of new knowledge of this particular topic. This will likely also influence the possibility to engage with different networks and forums internally and externally, which relates to knowledge resources in terms of the organisations' openness to new ideas and the possibility to establish a common frame concerning what this topic entails and how it can be addressed (Healey, Magalhaes, and Madanipour 1999). It can be assumed that the lack of such an official at the local level would be a nearly insurmountable hindrance to addressing these issues thoroughly.

The results concerning the status and importance of the comprehensive plan, as well as the energy plan and/or energy and climate strategy, indicate the need for and potential benefit of policy integration (Healey et al. 2003) that encompasses the content of these two policy documents, which represents the two key policy spheres for this topic. Ideally, it should be a two-way policy integration, i.e., one that integrates spatial relations in local energy and climate strategies and aspects of climate change mitigation into the comprehensive plan. Such a two-way policy integration of both strategic documents would bring coherence and clarity for officials who are guided by these strategic documents in their practice, something both case study municipalities aim to achieve in their ongoing planning processes. Then, the identified key positions, the comprehensive planner and the environmental/energy climate strategist, should be actively involved in these strategic planning processes in order to enhance the range of accessible knowledge resources and assure that these potential change agents are included in vital moments of the process (Healey, Magalhaes, and Madanipour 1999).

\subsection{Local Co-Operation in the Comprehensive Planning Process}

\subsubsection{Survey}

In terms of the internal co-operation in municipal strategic planning processes between the target groups of the surveys, about half of the energy and climate strategists participate actively in the comprehensive planning processes, as presented in Figure A2 in Appendix D. This is still a higher proportion relative to the active participation of comprehensive planners in the energy and climate strategic process, which was reported by less than one-third of the respondents (Figure A3 in Appendix D).

Figure 4 shows that the relevant municipal administrations have a high level of involvement in comprehensive planning processes. The same figure illustrates that municipal politicians often participate as well, but not as frequently as the other municipal administrations. Moreover, the local energy company and the local electricity grid operator participated in only about a fifth of the comprehensive planning processes (Figure 4).

\subsubsection{Case Study Municipalities}

The forms of co-operation in the comprehensive planning processes differ between the case study municipalities. Both municipalities have formed broad cross-sectoral working groups consisting of officials from different departments that include all our interviewees. Moreover, the Danderyd officials frequently interact with their superiors and politicians, for example, as they held two workshops with the political steering group and municipal administration executives at the beginning of the process, prior to the workshops arranged by the research project. This workshop also addressed the content of the Environmental and Climate Programme and how to relate this policy document to the comprehensive plan, i.e., how to address climate change mitigation aspects in spatial planning. This led to increased awareness among the attendees and gave the officials a mandate to include such aspects in the Comprehensive Plan. Contrarily, in the comprehensive planning of Nykvarn, the interaction with politicians is limited, and a political steering group had not yet been 
formed at the time of the interview, although two of the workshops arranged within the research project had already been held in order to support the comprehensive planning process.

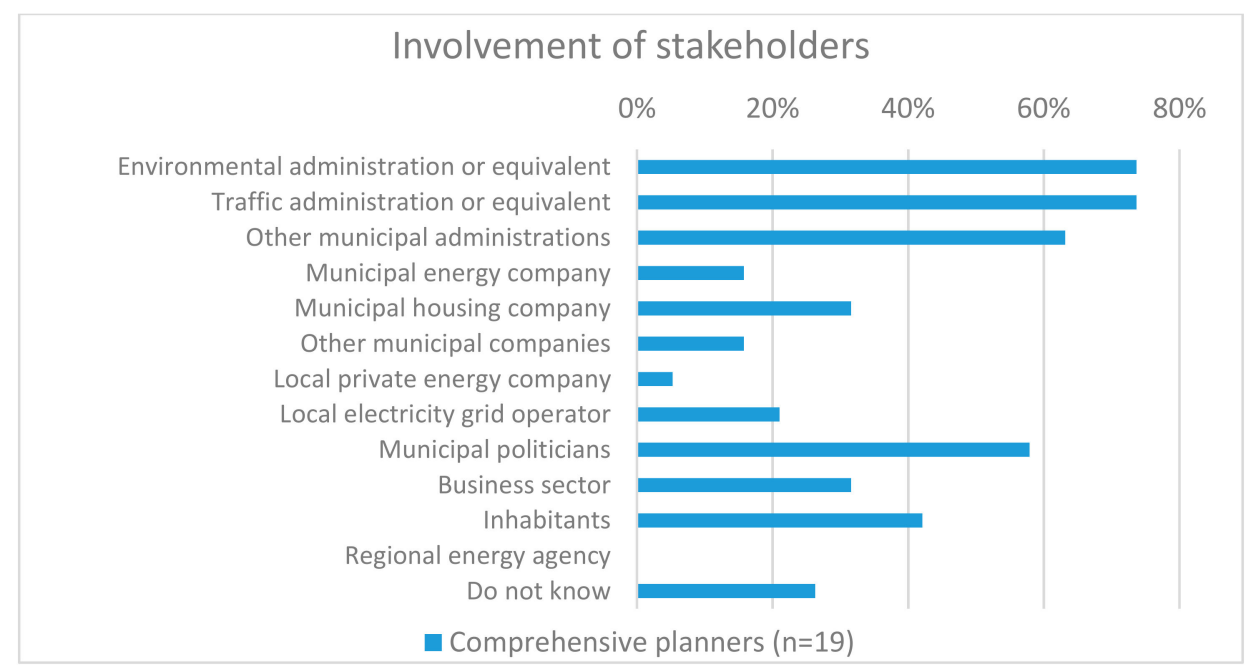

Figure 4. Involvement of stakeholders in the comprehensive planning process for addressing energy and climate strategic issues.

In general, it is worth noting how the composition of the participants at the workshops affects the content that is addressed and deemed important. For example, the electricity grid operator and the regional district heating company operating in Nykvarn participated in the workshops held there. This generated discussions regarding both the potential shortage of capacity in the Swedish national and regional electricity grids as well as the use of district heating for new developments. In contrast, such companies did not participate in the process-led workshops in Danderyd, but instead, a transport planner participated. Consequently, energy provision was not a concern brought up for discussion, but transportation was addressed more extensively and in greater detail than in Nykvarn.

\subsubsection{Analysis: Institutional Capacity Building}

From an institutional capacity perspective, this broad range of internal stakeholders included in the working groups of the case study municipalities should contribute to a wider range of accumulated knowledge and further contribute to this common frame [39]. The survey results indicate that this is generally common practice. The fact that external stakeholders, namely the regional district heating company and the electricity grid operator, participated in the comprehensive planning workshops in Nykvarn shows openness [14] and a willingness to interact. This co-operation, as mentioned, also led to substantial input into the process and more focus on energy production and distribution, when compared with Danderyd. These examples reaffirm the importance of working intersectorally and including a broad range of internal and external stakeholders in order to allow matters to be presented for a broader debate. In other words, it highlights the fact that the web of relations and their combined knowledge resources clearly affects to what extent and how these matters are being addressed. In light of the survey results, there is potential to involve more external stakeholders to strengthen the institutional capacity. This would especially apply to electricity grid operators and any district heating companies that operate in the municipality, as they possess vital knowledge and decisive power over highly relevant infrastructure.

Another difference between Nykvarn and Danderyd lies in the relations between the municipal officials and both the politicians and municipal administration executives, i.e., the relations to resource and allocating power (Healey et al. 2003). With the limited possibilities to interact with politicians in Nykvarn, substantial changes to the compre- 
hensive plan will probably be more difficult to present and gain approval for. This leads to a more closed organisation with little opportunity for mobilisation. In Danderyd, on the other hand, the officials seem to have more open and trust-based relations with the politicians and municipal executives, and have found an appropriate arena and repertoires for mobilisation (Healey et al. 2003) in their joint workshops. This may result in a higher degree of institutional change in terms of local planning and governance and a move towards a decarbonised society.

\subsection{Building Institutional Capacity through Networks for Inter-Municipal and Regional-Local Co-Operation \\ 5.3.1. Survey}

In terms of the forms of inter-municipal and regional-local co-operation considered necessary for strengthening the local capacity to integrate climate change mitigation aspects into spatial planning, survey responses in particular highlight the need for co-operation in inter-municipal matters, such as transport and a regional electric power deficit. Respondents also point to the need for increased regional political consensus in energy and climate-related issues. In addition, the exchange of knowledge and experience, increased collaboration between energy and climate strategists and physical planners, and spreading examples of best practices were emphasised.

\subsubsection{Case Study Municipalities}

When discussing external networks that address climate change mitigation aspects in spatial planning, the interviewees focused on two different types of governance networks where this issue can be addressed from time to time. One of these network types was the regional-local networks administered by the County Administrative Board, such as the comprehensive planner network and the energy and climate network. These networks cover the entirety of Stockholm County, and although they have specific municipal officials as their main target group, i.e., the comprehensive planning network targeting comprehensive planners and the energy and climate network targeting energy and climate strategists or similar, other officials can participate as well.

According to the interviewees, the main benefits are that they monitor relevant trends and initiatives nationally and globally and disseminate relevant information to municipal officials, and that they are spreading examples of best practices and diffusing theoretical knowledge through seminars. This view is shown in the following quote.

[The County Administrative Board] has a good function for highlighting matters that municipalities are not directly involved in but still are relevant. It can be to bring in experts from national agencies, those types of things ... It can also be to spread good examples.

(Environmental coordinator in Danderyd. Authors' translation.)

Another type of network that the interviewees deem to be important is sub-regional, intermunicipal networks. Nykvarn participates in one such network together with the seven other municipalities in the geographical area of Södertörn, and Danderyd is a member of the Stockholm Northeast network along with five other municipalities situated to the northeast of the city of Stockholm. Similarly, in terms of the co-operation administered by the County Administrative Board, both of these sub-regional alliances have sub-networks for certain municipal officials, such as comprehensive planners and environmental strategists, but they also have networks for the municipal mayors and the municipal chief executives from each municipality. The officials state that the fact that these two decisive posts participate in these sub-regional, inter-municipal networks adds to their legitimacy. Furthermore, as the environmental coordinator from Danderyd reports, this setting can spur action, as the municipal chief executives seek recognition that their municipality is performing well in comparison to the other municipalities.

These sub-regional networks are perceived by the interviewees as a more fruitful way to concretely address inter-municipal issues, such as inter-municipal transport (public 
transport, walking and cycling) and large-scale energy infrastructure, such as the electricity grid capacity issue. Moreover, as expressed in the quote below, the interviewees report that strong relational bonds can arise within the sub-networks, which can spur an enhanced, collegial exchange of knowledge and experience. This could include discussing general ideas or challenges and sharing drafts of policy documents for input.

Above all, you get good support. You are quite lonely at the municipality and immerse yourself in your field. Then it is good to talk to someone else. Are you doing it in the same way? Are we heading in the right direction? Do you have any good solutions or ideas or activities? Then you can include this.

(Environmental coordinator in Danderyd. Authors' translation.)

\subsubsection{Analysis: Institutional Capacity Building}

The interviews show that the regional-local network administered by the $\mathrm{CAB}$ and the sub-regional, inter-municipal networks brings different, complementary added value to the local capacity building. The regional-local network mainly seems to contribute to enhancing the range of local knowledge resources (Healey, Magalhaes, and Madanipour 1999) by spreading examples of best practices and diffusing more theoretical knowledge. Such networks also contribute to enhancing the relational resources to some extent, as practitioners meet and interact. The relational bonds built in the sub-regional, intermunicipal networks nevertheless seem to be stronger, thereby enabling the enrichment of the range of knowledge in a different way, as it facilitates the transfer of practical knowledge. Additionally, the morphology of the sub-regional networks, with different sub-networks not only for different officials but also for the municipal mayors and the municipal chief executives (i.e., the main resource and allocating power), creates an arena that, if an opportunity structure can be gained, brings more potential for mobilisation and action (Healey, Magalhaes, and Madanipour 1999). This was also shown by both case study municipalities, as concrete efforts were coordinated in these networks.

\section{Discussion}

Prior to discussing the findings of the paper, it is appropriate to present some methodological reflections. Concerning the case study selection, a disadvantage for a broader generalisability may be that they are situated in the same county and metropolitan region. Still, as highlighted in the presentation of the case study municipalities, they represent different types of municipalities, with Danderyd being more densely populated and having a more urban character, whereas Nykvarn represents a peri-urban/rural municipality. These differences add to the generalisability of the joint findings from the case study municipalities, as do the methodological triangulation. Additionally, the internal validity of the findings from the case studies is strengthened by employing two different methods for investigating their institutional capacity building, including both interviews and participation in workshops.

Through the applied lens of institutional capacity building, some critical components can be identified in terms of the capacities of the municipalities. This study shows the need to employ officials who are specifically tasked with addressing strategic energy and climate issues as well as the need to provide these officials with the resources and mandate needed to interact with the resource and allocating power (i.e., politicians). Moreover, the existence of a local policy document that addresses strategic energy and climate issues was found to be critical in order to enable the integration of the policy spheres of climate governance and strategic spatial planning. If this can be achieved, these two strategic policy documents would provide uniform guidance for other planning and decision-making within the municipality, which could be an essential first step to achieving institutional change. It should, however, be mentioned that this study only shows a snapshot of the current state of the institutional capacity building for the integration of energy and climate aspects into spatial planning, and that the outcome of the processes has not been studied in the case study municipalities due to their long duration. 
Relevant literature suggests that these identified critical components are also relevant to other areas in Sweden, as Wretling et al. [32], in a study of all Swedish municipalities, conclude that the presence and currency of local policy documents with a focus on energy and climate are significantly and positively related to the municipal population size, which presumably correlates with financial and personnel resources. Furthermore, in a case study of another Swedish city outside Stockholm county, Gustafsson et al. [40] (p. 15) conclude that "assuming that strategic spatial planning requires policy integration, there is a demand for resources, including time for politicians and planners to be involved and to communicate across fields of expertise and departments of the local authority organisation". This point towards the identified critical components for institutional capacity building not being dependant on any specific regional preconditions, but rather on the characteristics of the Swedish planning and governance system, where the municipalities uphold both decision-making powers concerning land use planning and extensive responsibilities in other areas for providing services to citizens. Thus, these critical components may well be of relevance in other countries with similar planning and governance structures, particularly in Nordic countries such as Denmark, Norway and Finland [41,42]. Moreover, a majority of the European countries, e.g., Austria, Belgium, France, Italy and the UK, have local planning instruments of both strategic character and regulatory nature [43]. With an identified need to further integrate energy policies into spatial planning (Ibid.), the identified critical components could be applicable in such countries as well.

The lessons drawn concerning the need to work intersectorally and with relevant external stakeholders can also be found in other European countries. De Pascali and Bagaini [44] find that most Italian municipalities, like many other European Covenant of Mayors signatories, fail to consider aspects that are more closely connected to urban form and spatial planning, such as transport and energy production and supply, and that local energy and climate planning is rather kept as a sectorial activity. This issue is partly attributed to limited capacity building and the challenge of co-operating between local public departments, leading to conflicts regarding responsibilities and powers (Ibid.). Furthermore, in a comparative case study of three mid-sized cities in Sweden, Finland and Estonia, Große et al. [45] (p. 34) find that local power relations are critical for being able to spatially plan for more energy-efficient urban structures, including "the interplay between municipal planning competences, the involvement of stakeholders as well as coordination between neighbouring municipalities and regional planning bodies". In the Swedish case study, Eskilstuna, the municipally-owned energy supply company is identified as integral for Eskilstuna's ability to carry out their energy and climate-related strategies with a high level of effectiveness (Ibid.). This paper adds to this research by highlighting that even if the district heating company and electricity grid operator operating in the municipality are not municipally owned, they are still key actors for being able to thoroughly address the interplay of spatial development and energy system configuration. Furthermore, the fact that it seems uncommon to engage with such influential actors if they are not a part of the municipal concern must be considered to hinder Swedish municipalities in fully exploring and exploiting potential pathways for decarbonisation.

The analysis illuminates the importance of the different types of regional governance networks (i.e., both the regional-local networks administered by the CABs and the two different sub-regional, inter-municipal networks) that the municipalities are embedded in for building their institutional capacity in complementary ways. These two networks can be categorised as two different types of territorial networking, as identified by Kern [46], that fill an important role in what is referred to as embedded upscaling of local experiments and serve as examples to medium-sized cities and towns, thereby closing the gap between local authorities that can be characterised as leaders, followers and laggards in terms of climate action. The findings of this paper thus indicate that the role of regional networks is of similar importance in terms of institutional capacity building for the integration of climate change mitigation aspects into strategic spatial planning as they are for the broader umbrella of climate governance. Results that support this claim have been presented by 
Medeiros and van der Zwet [47], who studied the design and implementation process of Integrated Strategies for Sustainable Urban Development in the metropolitan urban area of Barcelona, where a network of four urban areas of Catalonia fostered sharing of experiences and enabled further collaboration. In sum, this indicates a broader generalisability for the significant role of different governance networks at the regional and sub-regional level to foster a more sustainable and integrated spatial planning practice.

Furthermore, Kern [46] highlights the emergence of functional networks, meaning networks of officials with the same position, which can be found, for example, in Germany. Notably, both types of studied regional networks, especially the inter-municipal subregional networks, can be characterised as having multiple functional networks within the territorial network. The analysis indicates that the combination of these two types of networks is a key trait for their added value for building institutional capacity, as it allows inter-municipal issues to be addressed while simultaneously building relational bonds and exchanging examples of best practices and practical knowledge. Potentially, such complementary regional-local and inter-municipal, sub-regional governance networks could fulfil similar functions for the institutional capacity building also in other countries, and they may thereby have a role to play in multi-level climate governance on a global scale as to facilitate and accelerate the rate of decarbonisation of our societies in line with the Paris Agreement.

As all Swedish County Administrative Boards have been given the task of developing Regional Climate and Energy Strategies and coordinating regional efforts, initiatives to such regional-local networks may have risen also in other counties. It is thus likely that they play a more prominent role within Swedish multi-level climate governance than what may seem to be the case from a cross-country comparison of the prevalence and role of Covenant Territorial Coordinators within Covenant of Mayors, where Sweden had merely one such territorial coordinator at the time of study [48]. The existence of the inter-municipal, sub-regional networks that both Danderyd and Nykvarn participates in may be more dependant of the fact that the case study municipalities belong to a metropolitan region. This is due to the fact that a key motivation for the co-operation in Stockholm Northeast was to have a common voice when bargaining for transport infrastructure investments against regional and national authorities [49]. Nevertheless, topics such as peer-to-peer learning at regional and local governance levels as well as interactions between such different levels remain under-researched [50], and more research is needed to understand the prevalence of such inter-municipal, sub-regional networks and their added value in more detail.

Against the backdrop of multi-level governance, it is evident that the CAB is perceived as an important regional actor in the coordination of energy and climate strategic efforts. This is inferred from the fact that the CAB's Regional Climate and Energy Strategy is recognised as influential in municipal planning by energy and climate strategists, and that their respective networks for comprehensive planners and energy and climate strategists are considered vital channels for dissemination of relevant information and knowledge as well as spreading examples of best practices. Such a position could help the CAB act as a meta-governor, steering other independent actors in the direction of their strategy and their targets, in line with the findings of Palm and Thoresson [36]. As municipal spatial planning will play a decisive role in determining whether regional climate targets will be met, it could be recommended that the CABs internalise a continual network forum for the integration of climate change mitigation aspects into spatial planning, if they are to successfully contribute to the attainment of their established targets as a part of their meta-governor role.

In light of the fact that climate change is a wicked problem and that knowledge, technology and practices for integrating such aspects into spatial planning evolving rapidly, there will be a constant need for municipalities to be able to absorb new knowledge and adapt. As pointed out by Healey et al. [16], having a strong institutional capacity but not being able to adapt to external pressure leads to inertia. As the current trajectory of climate change could set us on the path towards about $3{ }^{\circ} \mathrm{C}$ of warming by 2100 [51], 
a lack of transformation would be highly problematic, ultimately further intensifying the external pressure. This points towards the likelihood that the transformational process of the municipalities' institutional capacity will continue in the coming decades and further accentuates the vital role that regional-local and inter-municipal networks of different kinds may uphold in this context.

\section{Conclusions}

From this study, which concerns the process of integrating climate change mitigation aspects into spatial planning from the perspective of institutional capacity building, the following conclusions can be drawn. Firstly, it highlights how dimensions of institutional capacity interact and identifies some critical components needed to enable institutional capacity building. These critical components include the need for dedicated personnel working with energy and climate strategic issues, with a mandate and the resources needed to interact with the resource and allocating power and with a municipal policy document that addresses strategic energy and climate issues, such that they have a policy sphere to integrate into spatial planning. By examining the applicability of this theoretical framework concerning the integration of climate change mitigation aspects into spatial planning, the identification of these critical components could serve as a knowledge basis for the development of guidelines and/or policy formulation at the national and regional level, to support the local authorities in this endeavour. As the impacts of climate change are becoming increasingly evident, the demand for institutional capacity building concerning the integration of climate change mitigation aspects at local authorities will intensify, and virtually all local authorities will need to undergo this transformational process, not only in Sweden but also elsewhere.

Secondly, the study shows the need for co-operating intersectorally within the organisation in the comprehensive planning process to build institutional capacity. Furthermore, it is essential to involve influential external stakeholders such as the electricity grid operator and district heating company in order to be able to thoroughly address energy and climate aspects in the comprehensive planning process in an integrated manner, as a part of a more sustainable spatial planning practice, which seldom is the case as of today.

Thirdly, the study highlights how regional-local networks administered by the County Administrative Board and sub-regional, inter-municipal networks contribute to the local institutional capacity building in complementary ways by disseminating different types of knowledge. The latter type of network also seems to spur concrete action concerning inter-municipal energy and climate issues through inter-municipal co-operation. If the national and global climate targets are to be met, both of these types of networks need to be promoted, so that municipalities can obtain new knowledge and practices and transform their institutional capacity in response to the need to achieve climate neutrality.

Lastly, some suggestions for future research can be made. The findings of the study imply that many municipalities are in a transformational phase of building institutional capacity for integrating climate change mitigation aspects into spatial planning. This notion could be explored in greater depth by investigating how the municipalities' abilities to address such concerns develop over time.

Author Contributions: Conceptualization, V.W.; methodology, V.W. and B.B.; formal analysis, V.W.; investigation, V.W.; writing—original draft preparation, V.W.; writing—review and editing, V.W. and B.B.; visualization, V.W.; supervision, B.B.; project administration, V.W.; funding acquisition, B.B. All authors have read and agreed to the published version of the manuscript.

Funding: This research was funded by the Swedish Energy Agency, grant number 47308-1. The APC was funded by KTH Library.

Informed Consent Statement: Informed consent was obtained from all subjects involved in the study.

Acknowledgments: The authors wish to thank Anna-Lena Lövkvist Andersen at the County Administrative Board of Stockholm for fruitful discussions and project collaboration. We also want to thank the interviewees for their participation in the study. 
Conflicts of Interest: The authors declare no conflict of interest. The funders had no role in the design of the study; in the collection, analyses, or interpretation of data; in the writing of the manuscript, or in the decision to publish the results.

\section{Appendix A}

Table A1. Key statistics on case study municipalities [52].

\begin{tabular}{cccccc}
\hline & $\begin{array}{c}\text { Population } \\
\text { Size }\end{array}$ & Total Area & Inhabitants/km $\mathbf{k m}^{2}$ & $\begin{array}{c}\text { Proportion of Inhabitants } \\
\text { Living in Urban Settlements }\end{array}$ & $\begin{array}{c}\text { Proportion of Land } \\
\text { Used for Settlements }\end{array}$ \\
\hline Danderyd & 33,000 & $26 \mathrm{~km}^{2}$ & 1246 & $100 \%$ & $53 \%$ \\
\hline Nykvarn & 11,000 & $153 \mathrm{~km}^{2}$ & 72 & $81 \%$ & $8 \%$ \\
\hline
\end{tabular}

\section{Appendix B}

Table A2. Interview guide for the conducted semi-structured interviews.

\section{Interview Guide}

1. Does the municipality carry out any work to integrate aspects related to climate change mitigation and energy efficiency in spatial planning? If so, in what way? Which focus areas/themes does this work address?

2. In which planning processes is it important to include these issues? In what way are these aspects integrated into these processes?

3. Who are the key internal actors for integrating these issues into spatial planning? Why are they important? How are they involved in the comprehensive planning process?

4. Who are the key external actors for integrating these issues into spatial planning? Why are they important? How are they involved in the comprehensive planning process?

a. Are there any external networks where, among other things, these issues are addressed?

5. Do you experience any challenges for an increased integration of energy and climate aspects into spatial planning?

6. Are there any challenges and opportunities linked to increased inter-municipal collaboration?

7. Are there any challenges and opportunities linked to increased regional-local collaboration?

\section{Appendix C}

Table A3. Participants at the comprehensive planning workshops of the case study municipalities. Each participant participated in all three workshops for each case study municipality, unless stated otherwise.

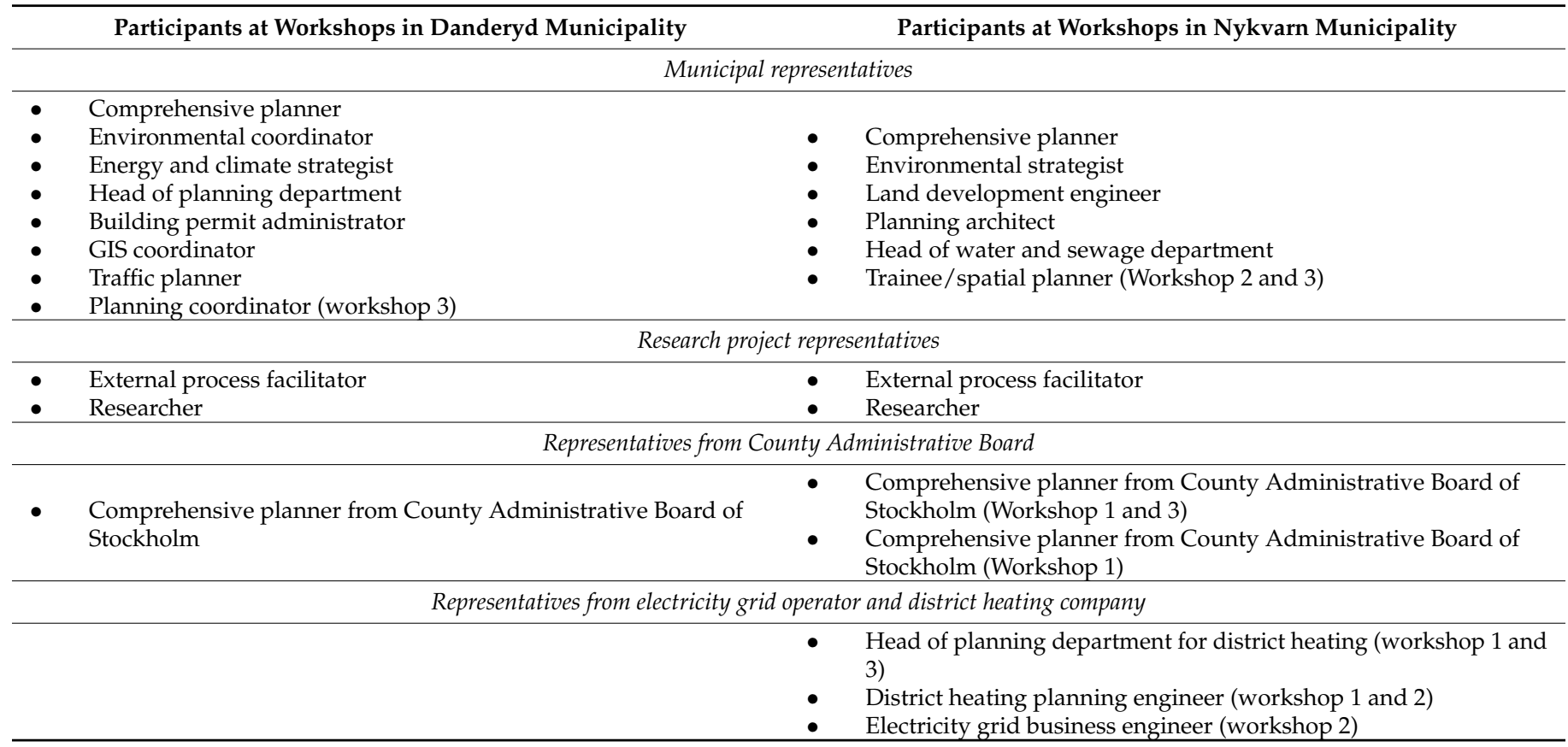




\section{Appendix D}

Which objectives, plans and strategies are the municipality using as guidance?

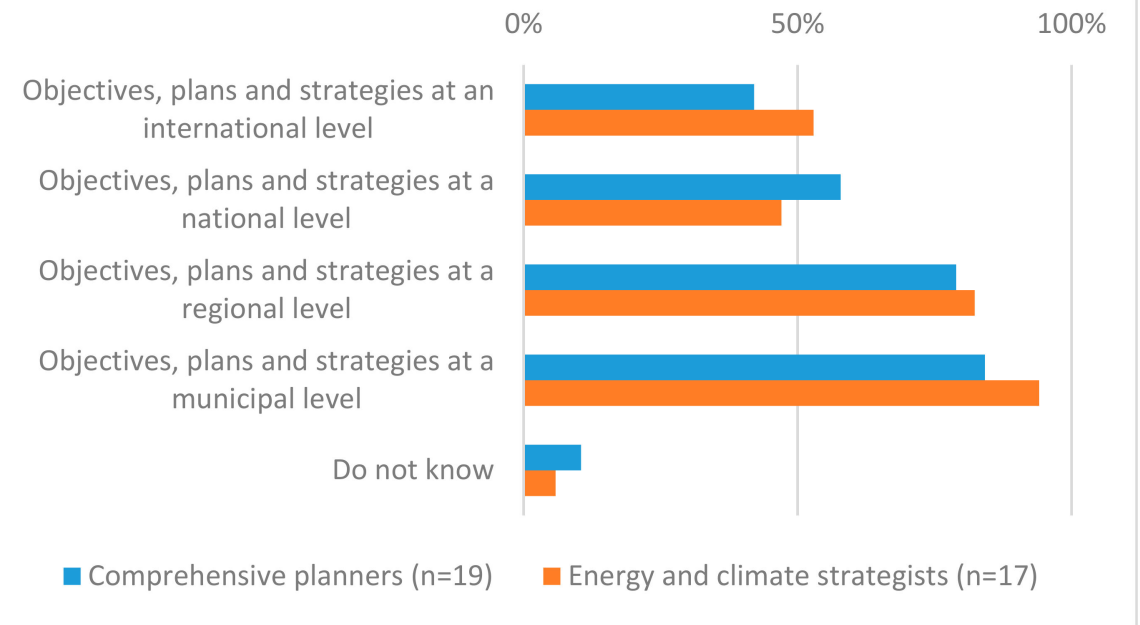

Figure A1. Government level of relevant objectives, plans and strategies.

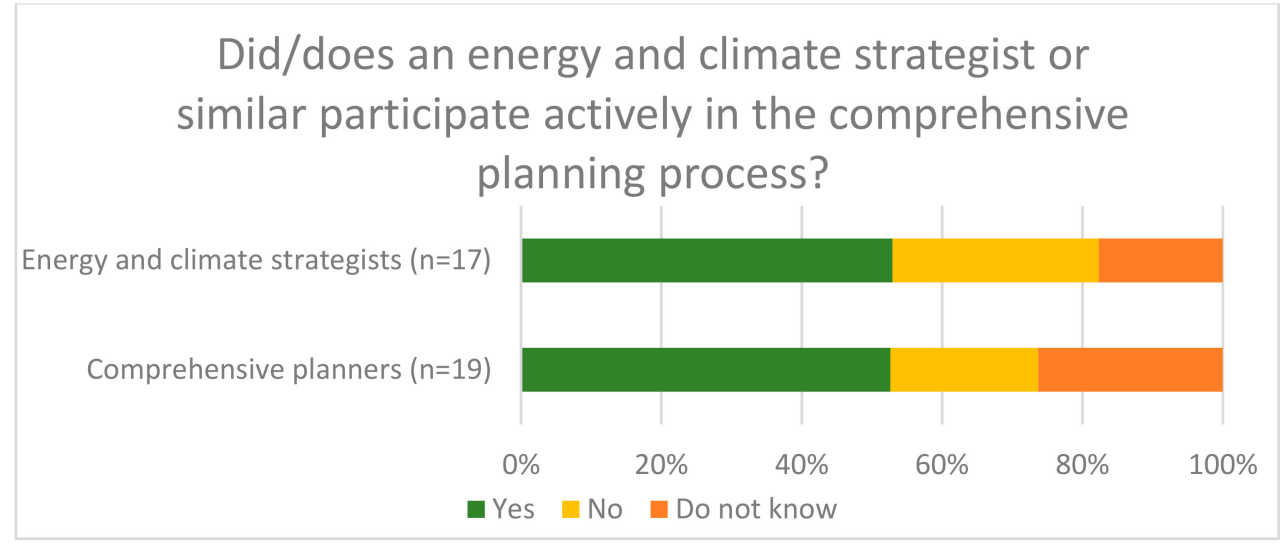

Figure A2. Participation of energy and climate strategist or similar in the comprehensive planning process.

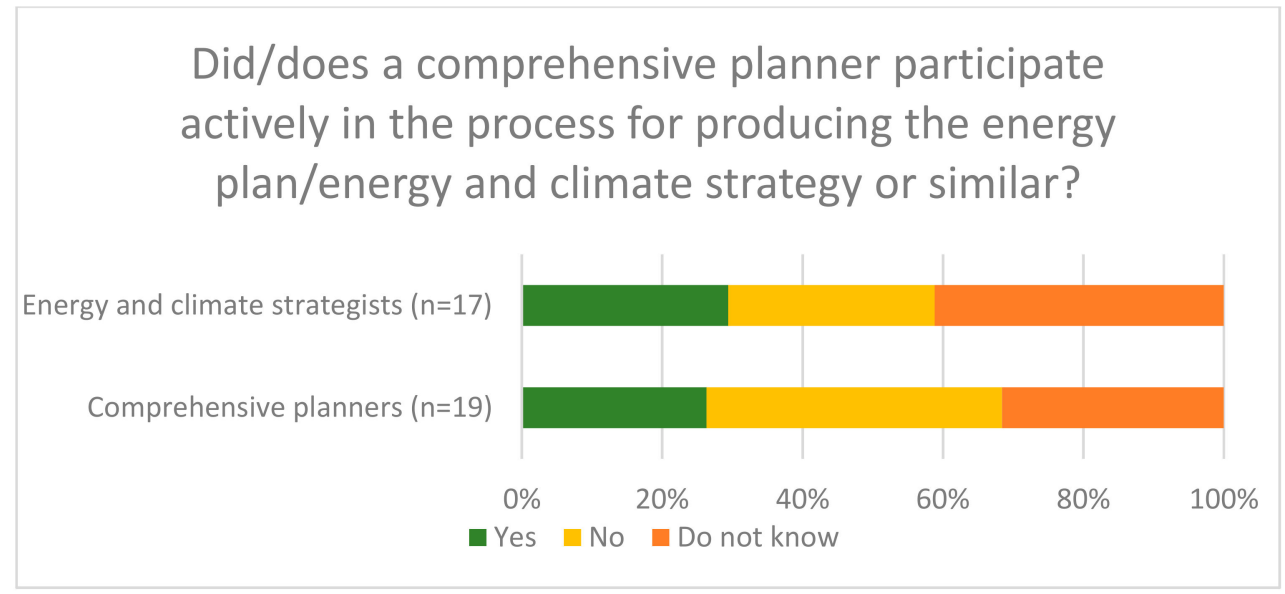

Figure A3. Participation of comprehensive planner in the process of developing energy plan/energy and climate strategy or similar. 


\section{References}

1. Levin, K.; Cashore, B.; Bernstein, S.; Auld, G. Overcoming the Tragedy of Super Wicked Problems: Constraining Our Future Selves to Ameliorate Global Climate Change. Policy Sci. 2012, 45, 123-152. [CrossRef]

2. Jänicke, M. The Multi-Level System of Global Climate Governance - the Model and Its Current State. Environ. Policy Gov. 2017, 27, 108-121. [CrossRef]

3. Kern, K.; Bulkeley, H. Cities, Europeanization and Multi-Level Governance: Governing Climate Change through Transnational Municipal Networks*. JCMS J. Common Mark. Stud. 2009, 47, 309-332. [CrossRef]

4. Busch, H.; Bendlin, L.; Fenton, P. Shaping Local Response - The Influence of Transnational Municipal Climate Networks on Urban Climate Governance. Urban Clim. 2018, 24, 221-230. [CrossRef]

5. Tang, Z.; Brody, S.D.; Quinn, C.; Chang, L.; Wei, T. Moving from Agenda to Action: Evaluating Local Climate Change Action Plans. J. Environ. Plan. Manag. 2010, 53, 41-62. [CrossRef]

6. Reckien, D.; Flacke, J.; Dawson, R.J.; Heidrich, O.; Olazabal, M.; Foley, A.; Hamann, J.J.-P.; Orru, H.; Salvia, M.; De Gregorio Hurtado, S.; et al. Climate Change Response in Europe: What's the Reality? Analysis of Adaptation and Mitigation Plans from 200 Urban Areas in 11 Countries. Clim. Chang. 2014, 122, 331-340. [CrossRef]

7. van Staden, M.; Musco, F. Local Governments and Climate Change: Sustainable Energy Planning and Implementation in Small and Medium Sized Communities; Springer Netherlands: Dordrecht, The Netherlands, 2010; Volume 39, ISBN 978-1-4020-9530-6.

8. Betsill, M.M.; Bulkeley, H. Cities and the Multilevel Governance of Global Climate Change. Glob. Gov. 2006, 12, 141-159. [CrossRef]

9. Stoeglehner, G. Integrated Spatial and Energy Planning: A Means to Reach Sustainable Development Goals. Evol. Institutional Econ. Rev. 2020, 17, 473-486. [CrossRef]

10. Cervero, R.; Kockelman, K. Travel Demand and the 3Ds: Density, Diversity, and Design. Transp. Res. Part Transp. Environ. 1997, 2, 199-219. [CrossRef]

11. Næss, P. Urban Form and Travel Behavior: Experience from a Nordic Context. J. Transp. Land Use 2012, 5, 21-45. [CrossRef]

12. Kaza, N.; Curtis, M.P. The Land Use Energy Connection. CPL Bibliogr. 2014, 29, 355-369. [CrossRef]

13. Healey, P.; De Magalhaes, C.; Madanipour, A.; Pendlebury, J. Place, Identity and Local Politics: Analysing Initiatives in Deliberative Governance. Deliberative Policy Anal. Underst. Gov. Netw. Soc. 2003, 60-87. [CrossRef]

14. Polk, M. Institutional Capacity-Building in Urban Planning and Policy-Making for Sustainable Development: Success or Failure? Plan. Pract. Res. 2011, 26, 185-206. [CrossRef]

15. Lindseth, G.; Reitan, M. The Urban Governance of Transport and the Environment in the City of Kristiansand. J. Environ. Plan. Manag. 2007, 50, 135-151. [CrossRef]

16. Healey, P.; de Magalhaes, C.; Madanipour, A. Institutional Capacity-Building, Urban Planning and Urban Regeneration Projects. Futura 1999, 18, 117-137.

17. Palm, J.; Lazoroska, D. Collaborative Planning through Dialogue Models: Situated Practices, the Pursuit of Transferability and the Role of Leadership. J. Environ. Plan. Manag. 2020. [CrossRef]

18. Healey, P. Collaborative Planning: Shaping Places in Fragmented Societies; Macmillan: Basingstoke, UK, 1997; ISBN 978-0-333-49573-5.

19. Andonova, L.B.; Betsill, M.M.; Bulkeley, H. Transnational Climate Governance. Glob. Environ. Polit. 2009, 9, 52-73. [CrossRef]

20. Gustavsson, E.; Elander, I.; Lundmark, M. Multilevel Governance, Networking Cities, and the Geography of Climate-Change Mitigation: Two Swedish Examples. Environ. Plan. C Gov. Policy 2009, 27, 59-74. [CrossRef]

21. Kern, K.; Alber, G. Governing Climate Change in Cities: Modes of Urban Climate Governance in Multi-Level Systems. In Proceedings of the international conference on Competitive Cities and Climate Change, Milan, Italy, 9-10 October 2009.

22. Jörby, S.A. Local Agenda 21 in Four Swedish Municipalities: A Tool towards Sustainability? J. Environ. Plan. Manag. 2002, 45, 219-244. [CrossRef]

23. Healey, P. Building Institutional Capacity through Collaborative Approaches to Urban Planning. Environ. Plan. Econ. Space 1998, 30, 1531-1546. [CrossRef]

24. Reimer, M. Planning Cultures in Transition: Sustainability Management and Institutional Change in Spatial Planning. Sustainability 2013, 5, 4653-4673. [CrossRef]

25. Hrelja, R.; Hjerpe, M.; Storbjörk, S. Creating Transformative Force? The Role of Spatial Planning in Climate Change Transitions Towards Sustainable Transportation. J. Environ. Policy Plan. 2015, 17, 617-635. [CrossRef]

26. Dymén, C.; Langlais, R. Adapting to Climate Change in Swedish Planning Practice. J. Plan. Educ. Res. 2013, 33, 108-119. [CrossRef]

27. Bjärstig, T.; Thellbro, C.; Stjernström, O.; Svensson, J.; Sandström, C.; Sandström, P.; Zachrisson, A. Between Protocol and Reality-Swedish Municipal Comprehensive Planning. Eur. Plan. Stud. 2018, 26, 35-54. [CrossRef]

28. Högström, J.; Balfors, B.; Hammer, M. Planning for Sustainability in Expansive Metropolitan Regions: Exploring Practices and Planners' Expectations in Stockholm, Sweden. Eur. Plan. Stud. 2018, 26, 439-457. [CrossRef]

29. Fenton, P.; Gustafsson, S.; Ivner, J.; Palm, J. Sustainable Energy and Climate Strategies: Lessons from Planning Processes in Five Municipalities. J. Clean. Prod. 2015, 98, 213-221. [CrossRef]

30. Gustafsson, S.; Ivner, J.; Palm, J. Management and Stakeholder Participation in Local Strategic Energy Planning-Examples from Sweden. J. Clean. Prod. 2015, 98, 205-212. [CrossRef] 
31. Lundqvist, L.J.; Kasa, S. Between National Soft Regulations and Strong Economic Incentives: Local Climate and Energy Strategies in Sweden. J. Environ. Plan. Manag. 2016, 60, 1092-1111. [CrossRef]

32. Wretling, V.; Gunnarsson-Östling, U.; Hörnberg, C.; Balfors, B. Strategic Municipal Energy Planning in Sweden-Examining Current Energy Planning Practice and Its Influence on Comprehensive Planning. Energy Policy 2018, 113, 688-700. [CrossRef]

33. Montin, S. Municipalities, Regions, and County Councils. 2016, pp. 367-382. Available online: https://www.academia.edu/1813 5956/Municipalities_Regions_and_County_Councils_in_Sweden_Actors_and_Institutions_School_of_Public_Administration_ Working_Papers_Series_2014_27 (accessed on 17 February 2021).

34. Antonson, H.; Isaksson, K.; Storbjörk, S.; Hjerpe, M. Negotiating Climate Change Responses: Regional and Local Perspectives on Transport and Coastal Zone Planning in South Sweden. Land Use Policy 2016, 52, 297-305. [CrossRef]

35. Lundqvist, L.J. Planning for Climate Change Adaptation in a Multi-Level Context: The Gothenburg Metropolitan Area. Eur. Plan. Stud. 2016, 24, 1-20. [CrossRef]

36. Palm, J.; Thoresson, J. Strategies and Implications for Network Participation in Regional Climate and Energy Planning. J. Environ. Policy Plan. 2014, 16, 3-19. [CrossRef]

37. Johnson, R.B.; Onwuegbuzie, A.J.; Turner, L.A. Toward a Definition of Mixed Methods Research. J. Mix. Methods Res. 2007, 1, 112-133. [CrossRef]

38. Kvale, S.; Brinkmann, S. InterViews: Learning the Craft of Qualitative Research Interviewing; SAGE Publications: Los Angeles, CA, USA, 2014; ISBN 978-1-4522-7572-7.

39. Vigar, G.; Healey, P. Developing Environmentally Respectful Policy Programmes: Five Key Principles. J. Environ. Plan. Manag. 2002, 45, 517-532. [CrossRef]

40. Gustafsson, S.; Hermelin, B.; Smas, L. Integrating Environmental Sustainability into Strategic Spatial Planning: The Importance of Management. J. Environ. Plan. Manag. 2018. [CrossRef]

41. Baldersheim, H.; Ståhlberg, K. From Guided Democracy to Multi-Level Governance: Trends in Central-Local Relations in the Nordic Countries. Local Gov. Stud. 2002, 28, 74-90. [CrossRef]

42. Hall, T. Planning and Urban Growth in Nordic Countries; Routledge: London, UK, 2003.

43. Nadin, V.; Fernández Maldonado, A.M.; Zonneveld, W.; Stead, D.; Dąbrowski, M.; Piskorek, K.; Sarkar, A.; Schmitt, P.; Smas, L.; Cotella, G.; et al. COMPASS—Comparative Analysis of Territorial Governance and Spatial Planning Systems in Europe: Applied Research 2016-2018: Final Report; ESPON: Oslo, Norway, 2018.

44. De Pascali, P.; Bagaini, A. Energy Transition and Urban Planning for Local Development. A Critical Review of the Evolution of Integrated Spatial and Energy Planning. Energies 2019, 12, 35. [CrossRef]

45. Große, J.; Fertner, C.; Groth, N.B. Urban Structure, Energy and Planning: Findings from Three Cities in Sweden, Finland and Estonia. Urban Plan. 2016, 1, 24-40. [CrossRef]

46. Kern, K. Cities as Leaders in EU Multilevel Climate Governance: Embedded Upscaling of Local Experiments in Europe. Environ. Polit. 2019, 28, 125-145. [CrossRef]

47. Medeiros, E.; van der Zwet, A. Sustainable and Integrated Urban Planning and Governance in Metropolitan and Medium-Sized Cities. Sustainability 2020, 12, 5976. [CrossRef]

48. Melica, G.; Bertoldi, P.; Kona, A.; Iancu, A.; Rivas, S.; Zancanella, P. Multilevel Governance of Sustainable Energy Policies: The Role of Regions and Provinces to Support the Participation of Small Local Authorities in the Covenant of Mayors. Sustain. Cities Soc. 2018, 39, 729-739. [CrossRef]

49. Rader Olsson, A.; Cars, G. Polycentric Spatial Development: Institutional Challenges to Intermunicipal Cooperation. Jahrb. Für Reg. 2011, 31, 155. [CrossRef]

50. Jänicke, M.; Wurzel, R.K.W. Leadership and Lesson-Drawing in the European Union's Multilevel Climate Governance System. Environ. Polit. 2019, 28, 22-42. [CrossRef]

51. Raftery, A.E.; Zimmer, A.; Frierson, D.M.W.; Startz, R.; Liu, P. Less than $2{ }^{\circ}$ C Warming by 2100 Unlikely. Nat. Clim. Chang. 2017, 7 , 637-641. [CrossRef]

52. Statistics Sweden Kommuner i Siffror-Tabeller Och Fördjupning. Available online: https://www.scb.se/hitta-statistik/sverige-isiffror / kommuner-i-siffror /\#?region1=0162\&region2=0140 (accessed on 8 June 2020). 